\title{
Effect Of G2706A and G1051A polymorphisms of the $A B C A 1$ gene on the lipid, oxidative stress and homocystein levels in Turkish patients with polycystic ovary syndrome
}

Muammer Karadeniz ${ }^{6 *}$, Mehmet Erdoğan ${ }^{1}$, Zengi Ayhan ${ }^{1}$, Murat Yalıın ${ }^{5}$, Murat Olukman ${ }^{4}$, Sevki Cetinkalp ${ }^{1}$, Gulinnaz E Alper ${ }^{2}$, Zuhal Eroglu ${ }^{3}$, Asli Tetik ${ }^{3}$, Vildan Cetintas ${ }^{3}$, Ahmet G Ozgen ${ }^{1}$, Fusun Saygllı and Candeger Yılmaz

\begin{abstract}
Background: Obesity, insulin resistance and hyperandrogenism, crucial parameters of Polycystic ovary syndrome (PCOS) play significant pathophysiological roles in lipidemic aberrations associated within the syndrome. Parts of the metabolic syndrome (low HDL and insulin resistance) appeared to facilitate the association between PCOS and coronary artery disease, independently of obesity. ABCA1 gene polymorphism may be altered this components in PCOS patients.

In this study, we studied 98 PCOS patients and 93 healthy controls. All subjects underwent venous blood drawing for complete hormonal assays, lipid profile, glucose, insulin, malondialdehyde, nitric oxide, disulfide levels and ABCA genetic study.

Results: In PCOS group fasting glucose, DHEAS, 17-OHP, free testosterone, total-cholesterol, triglyceride, LDLcholesterol and fibrinogen were significantly different compare to controls. The genotype ABCA G2706A distribution differed between the control group (GG 60.7\%, GA 32.1\%, AA 7.1\%) and the PCOS patients (GG 8.7\%, GA 8.7\%, AA 76.8\%). The frequency of the A allele (ABCAG2706A) was higher in PCOS patients than control group with $13,0 \%$ and $23,2 \%$, respectively. In this study, the homocystein and insulin levels were significantly higher in PCOS patients with ABCA G1051A mutant genotype than those with heterozygote and wild genotypes.
\end{abstract}

Conclusions: We found higher percentage of AA genotype and A allele of ABCA G2706A in PCOS patients compare to controls. The fasting insulin and homocystein levels were significantly higher in PCOS patients with ABCA G1051A mutant genotype than those with heterozygote and wild genotypes.

\section{Introduction}

Polycystic ovary syndrome (PCOS) is one of the most common endocrine diseases and typically presents with chronic anovulation and hyperandrogenism [1]. PCOS is a common endocrine disorder, affecting between $4 \%$ and $8 \%$ of the women of reproductive age [2]. PCOS usually arises during puberty and is marked by hyperinsulinemia and hyperandrogenism. Adolescents with PCOS have an

\footnotetext{
* Correspondence: muammermd@hotmail.com

${ }^{6}$ Department of Endocrinology, Sifa University, Health Application and Research Center, Izmir, Turkey

Full list of author information is available at the end of the article
}

increased risk of developing health problems later on in life such as type 2 diabetes, cardiovascular disease, and infertility [3]. Studies suggest that PCOS is associated with increased risk of coronary heart disease (CHD) [4]. Elevated plasma Hcy levels and oxidative stress parameters are considered as an independent risk factor for CVD [5-7].

Dyslipidemia is possibly the most common metabolic abnormality of PCOS, although the findings of relevant studies have been variable and a substantial percentage of women with PCOS might still have normal lipid profiles

\section{Ciomed Central}

(c) 2011 Karadeniz et al; licensee BioMed Central Ltd. This is an Open Access article distributed under the terms of the Creative Commons Attribution License (http://creativecommons.org/licenses/by/2.0), which permits unrestricted use, distribution, and reproduction in any medium, provided the original work is properly cited. 
[8]. Qualitative alterations of lipoproteins have also been described in PCOS [9].

Obesity, IR and hyperandrogenism, crucial parameters of PCOS play significant pathophysiological roles in lipidemic aberrations associated with the syndrome. IR represents another key factor implicated in the dyslipidemia of PCOS. Glueck et al. reported that $46 \%$ of women with PCOS suffered from the metabolic syndrome. Within this subgroup of women, lipid abnormalities were found to be extremely common. $95 \%$ of these women demonstrated decreased levels of high-density-lipoprotein (HDL), whereas $56 \%$ had hypertriglyceridemia [10].

Lean women with PCOS were shown to have decreased $\mathrm{HDL}$ and $\mathrm{HDL}_{2}$ levels when compared to women with normal ovarian function, whereas obese PCOS women also had elevated triglyceride levels [11].

Hyperlipidemia was frequently connected with the disorders in apolipoproteins, receptors, enzymes, or cofactors in proteins related to lipoprotein metabolism. The changes happened in $\mathrm{ABCA} 1$ gene can play an important role amongst these changes. ABCA1 gene was considered to be responsible for the cause of Tangier disease [12].

Luciani and collagues were defined $A B C$ transporter family for the first time in 1994. ATP-binding cassette (ABC) genes encode a large family of transmembrane proteins. These proteins bind ATP in order to control the transition of different molecules (such as cholesterol) from cell membranes [13].

This study aims at exploring the association between metabolic, oxidative stress parameters (including malondialdehyde, (MDA) nitric oxide (NO) and disulfide levels $(\mathrm{SH})$ and demographic parameters and $\mathrm{ABCA} 1$ gene polymorphisms in polycystic ovary syndrome patients.

\section{Materials and methods Patients}

In this study, we studied 98 PCOS patients and 93 healthy controls. All researchs with human samples were done with written informed consent of the patients and with approval of the ethical committee of the Ege Universty Hospital. The patients had been referred to the Endocrinology and Metabolism Disease outpatient clinic at the Ege University Hospital. PCOS was defined by the Rotterdam PCOS consensus criteria [14]. Patients who had DM, hyperprolactinemia, congenital adrenal hyperplasia (diagnosed with the adrenocorticotropic hormone stimulation test), thyroid disorders, Cushing's syndrome, hypertension, hepatic or renal dysfunction were excluded from the study. Confounding medications, including oral contraceptive agents, hypertensive medications and insulin-sensitizing drugs, and those which may affect the metabolic criteria were questioned. Another 93 healthy young volunteer females matched for age, body mass index (BMI), and allele frequency were included from the study, and considered as the control group. Their health state was determined by medical history, physical and pelvic examination, and complete blood chemistry. The patients with PCOS and the control group were genetically unrelated.

\section{Study protocol}

At study entry, all subjects underwent venous blood drawing for complete hormonal assays, lipid profile, glucose, insulin and ABCA genetic study. All blood samples were obtained in the morning between 08.00 and 09.00 hours after an overnight fasting, and resting in bed during early follicular phase of the spontaneous or P-induced menstrual cycle. During the same visit, all subjects underwent anthropometric measurements including BMI and detail history, systolic and diastolic blood pressure. In present study, data related to the serum malondialdehyde, nitric oxide and disulfide levels, homocystein and fibrinogen levels and the genetic evaluation of $\mathrm{ABCA}$ will be shown and discussed.

\section{Biochemical assay}

Serum total cholesterol, LDL and HDL cholesterol were measured by Olympus AU 2700 automated analyzer. Plasma insulin concentrations were determined by Immunolite 2000 using two-site chemiluminescent immunometric assay.

\section{Methods for plasma MDA, NO, total sulfhydryl group measurements}

All reagents were purchased from Sigma and Merck. MDA was determined by a modified spectrophometric method of Yagi K [15] using tetrametoxypropan as Standard and BioTek MicroQuant microplate reader. NO was determined by measuring stable $\mathrm{NO}$ end-products-nitrite and nitrate levels using Miranda's spectrophometric method [16], while total sulfhydryl groups was measured using Ellman's reagent by Sedlak and Lindsay's method [17].

\section{Measurement of plasma homocysteine}

Venous blood samples were centrifuged at $1000 \times \mathrm{g}$ for 10 min and the serums were stored at $-80^{\circ} \mathrm{C}$ until the analysis -not exceeding three months. In this study, serum total homocysteine levels were measured by Fluorescence Polarization Immunoassay Method (IMX Homocysteine Assay, Abbott Diagnostics No: 7D29-20). Dilution method was used for those whose serum homocysteine levels were higher than $50 \mu \mathrm{mol} / \mathrm{L}$. All samples were prepared as $200 \mu$ l. Three controls were used in each sample for calibration of the device. For each of the controls, the results including ranges were accepted as low control (5, 25-8, 75), medium control (10.0-15.0), and high control (20.0-30.0) $\mu \mathrm{mol} / \mathrm{ml}$. 


\section{Genetic Analysis}

DNA isolations were carried out by using High Pure PCR Template Preparation Kit (Roche Applied Science, Germany) from peripheral blood samples of control and study group cases taken to tubes with EDTA.

For ABCA 1 G1051A polymorphism analysis, by using Forward Primer: 5'-CTC CAA AAGACT TCA AGG ACC C-3', Reverse Primer: 5'-GGC CCA AAA GTC TGA AAG AAC AC-3' primer pair, a DNA fragment of 433 base pairs is amplified by PCR method. For each sample, $25 \mu \mathrm{l}$ of prepared PCR reaction mixture contains $16,75 \mu \mathrm{l}$ of sterile distilled water, $0,5 \mu \mathrm{l}$ of Forward primer $(100 \mathrm{p} \mu \mathrm{l})$, $0,5 \mu \mathrm{l}$ of Reverse primer (100 p $\mu \mathrm{l}), 2,5 \mu \mathrm{Mg}^{+2}(25 \mathrm{mM})$, $2 \mu \mathrm{l}$ of dNTP mixture ( $2 \mathrm{mM}), 0,25 \mu \mathrm{l}$ of Taq DNA polymerase $(5 \mathrm{U} / \mu \mathrm{l})$, and $2,5 \mu \mathrm{l}$ of genomic DNA.

\section{i - PCR amplification}

Denaturation is carried out at $95^{\circ} \mathrm{C}$ for 2 minutes, amplification at $94^{\circ} \mathrm{C}$ for 30 seconds as 35 cycles, 1 minute at $72^{\circ} \mathrm{C}$, prolongation at $72^{\circ} \mathrm{C}$ for 7 minutes by applying PCR protocol.

For ABCA1 G2706A polymorphism analysis, DNA fragment of 350 base pairs is amplified by using Forward Primer: 5'-CAA GTG AGT GCT TGG GAT TG-3', Reverse Primer: 5'-TGC TTT TAT TCA GGG ACT CCA-3' primer pairs by PCR method. For each sample, $25 \mu \mathrm{l}$ of PCR reaction mixture contains $17,25 \mu \mathrm{l}$ of sterile distilled water, $0,5 \mu \mathrm{l}$ of Forward primer $(100 \mathrm{p} \mu \mathrm{l}), 0,5 \mu \mathrm{l}$ of Reverse primer (100 p $\mu \mathrm{l}), 2,5 \mu \mathrm{l} \mathrm{Mg}^{+2}(25 \mathrm{mM}), 1,5 \mu \mathrm{l}$ of $\mathrm{dNTP}$ mixture $(2 \mathrm{mM}), 0,25 \mu \mathrm{l}$ of Taq DNA polymerase $(5 \mathrm{U} / \mu \mathrm{l})$, and $2,5 \mu \mathrm{l}$ of genomic DNA.

\section{ii - PCR amplification}

Denaturation is carried out for ten minutes at $94^{\circ}$, amplification for 30 seconds at $94^{\circ} \mathrm{C}$ as 40 cycles, for 45 seconds at $52^{\circ} \mathrm{C}, 1$ minutes at $72^{\circ} \mathrm{C}$, prolongation for 7 minutes at $72^{\circ} \mathrm{C}$ by applying PCR protocol. The size of the products obtained after PCR is controlled at gel electrophoresis. PCR products made for the analysis of ABCA 1 G1051A and G2706A gene polymorphisms are evaluated in agarose gel of $2 \%$.

G1051A polymorphism analysis of -ABCA 1 gene is carried out at $37^{\circ} \mathrm{C}$ for 6 hours by incubating RFLP reaction mixture of $30 \mu \mathrm{l}$ containing $17 \mu \mathrm{l}$ of distilled water, $10 \mu \mathrm{l}$ of PCR product, $2 \mu \mathrm{l}$ of Buffer O, and $1 \mu \mathrm{l}$ of EcoO109I enzyme.

G2706A polymorphism analysis of -ABCA 1 gene is carried out by incubating at $30^{\circ} \mathrm{C}$ for 3 hours the mixture of RFLP reaction of $30 \mu \mathrm{l}$ containing $17 \mu \mathrm{l}$ of distilled water, $10 \mu \mathrm{l}$ of PCR product, $2 \mu \mathrm{l}$ of Buffer $\mathrm{O}$, and $1 \mu \mathrm{l}$ of BsaAI enzyme.

Genotyping is carried out after having conducted and displayed the products obtained as a result of enzyme cut for G1051A polymorphism analysis of ABCA 1 gene in agarose gel of $2 \%$ and in agarose gel of 3\% for G2706A polymorphism analysis.

As a result of G1051A polymorphism analysis, DNA fragments of sizes of 189 base pairs, 131 base pairs, and 113 base pairs in cases of wild genotype, 320 base pairs, 189 base pairs, 131 and 113 base pairs in heterozygote cases, and 320 base pairs and 113 base pairs in mutant cases are obtained (Figure 1). As a result of G2706A polymorphism analysis, DNA fragments of sizes of 252 base pairs and 98 base pairs in cases of wild genotype, 350 base pairs, 252 base pairs and 98 base pairs in heterozygote cases, and 350 base pairs in mutant cases are obtained (Figure 2).

\section{Results}

I-Demographic, metabolic and oxidative stress parameters of patients and controls

The demographic, hormonal and metabolic parameters of the PCOS and control groups are shown in Table 1. In the PCOS group fasting glucose, DHEAS, 17-OHP, free testosterone, total-cholesterol, triglyceride, LDL-cholesterol and fibrinogen were significantly $(\mathrm{P}<0.05)$ different in comparison with healthy women (Table 1). The fasting glucose levels were significantly $(\mathrm{P}<0.05)$ higher in PCOS than in control women, whereas no difference was observed in fasting insulin concentrations between the groups (Table 1). No significant differences were detected in age, weight, BMI, homocystein, MDA, NO, SH,

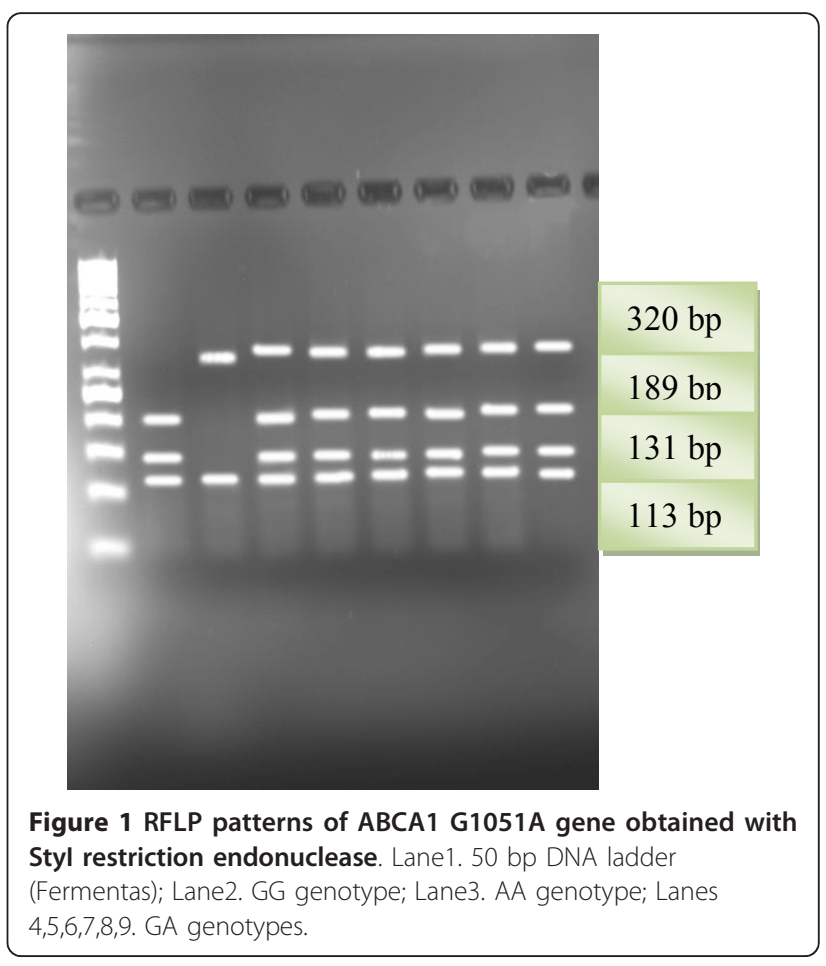




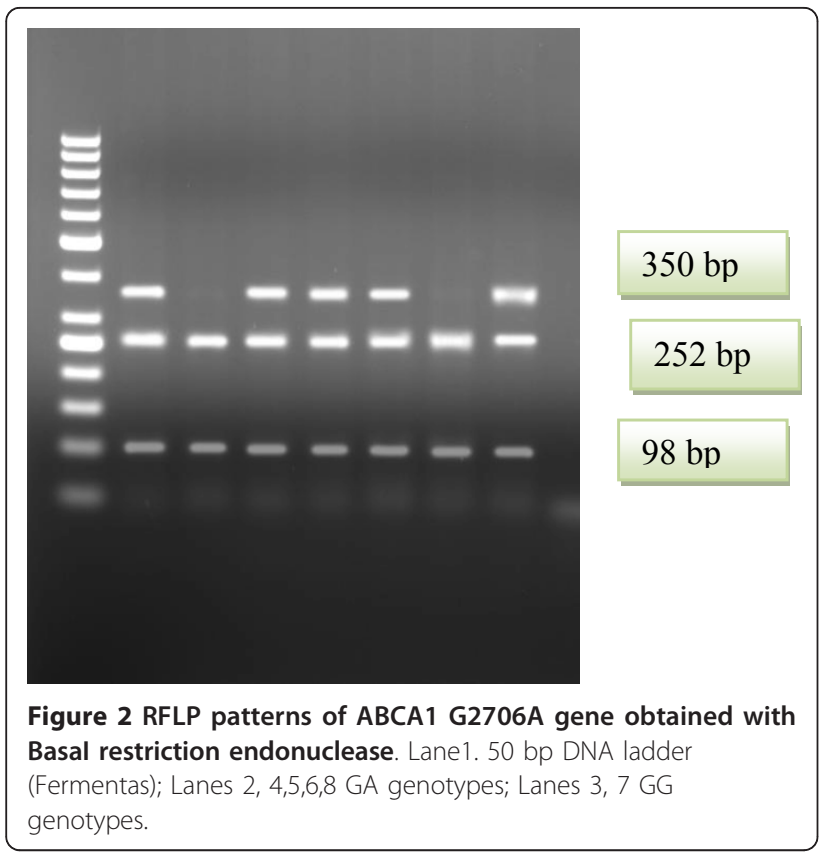

estradiol, DHEAS, prolactin, HDL-cholesterol levels between two groups (Table 1).

\section{II-Allelic distributions and ABCA genotype frequencies in patients}

The frequency of ABCA G1051A and G2706A polymorphism are shown in Table 2. The allelic distribution of ABCA genotypes was in Hardy-Weinberg equilibrium for both groups of women.

The genotype ABCA G1051A distribution didn't differ between the control group (GG 31.2\%, AG 53.8\%, AA $15.1 \%$ ) and the PCOS patients (GG 36.6\%, AG 52.7\%, AA 10.8\%) $(\mathrm{P}>0.05)$ The genotype ABCA G2706A distribution differed between the control group (GG 60.7\%, GA $32.1 \%$, AA $7.1 \%$ ) and the PCOS patients (GG 8.7\%, GA $8.7 \%$, AA $76.8 \%)(\mathrm{P}<0.05)$. The frequency of the polymorphic A allele (ABCA G2706A) was higher in PCOS patients than control group with $13,0 \%$ and $23,2 \%$, respectively $(\mathrm{p}=0.027$, OR:2.016; Table 2).

\section{III-Effects of ABCA genotypes on lipid profile,} demographic and other metabolic parameters in patients There was no statistically significant difference in PCOS patients between ABCA G1051A genotypes (AA, GA and GG) and BMI, fasting insulin, fasting glucose, triglyceride levels, HDL levels, LDL levels, fasting blood glucose levels, $\mathrm{f}$-testosterone, fibrinogen and 17-OHP levels $(\mathrm{p}>0.05$; Table 3). The fasting insulin level was significantly higher in PCOS patients with ABCA G1051A mutant genotype than those with heterozygote and wild genotypes (Table 3). No statistically meaningful difference was determined between polymorphism and lipid and other parameter
Table 1 Clinical characteristics of patients and controls

\begin{tabular}{|c|c|c|c|c|c|}
\hline \multirow[b]{3}{*}{ Age (years) } & \multirow{2}{*}{\multicolumn{2}{|c|}{$\begin{array}{c}\text { Control Group } \\
\text { Mean } \pm \text { SD }\end{array}$}} & \multirow{2}{*}{\multicolumn{2}{|c|}{$\begin{array}{c}\text { PCOS Group } \\
\text { Mean } \pm \text { SD }\end{array}$}} & \multirow{3}{*}{$\begin{array}{c}\mathbf{p} \\
0,567\end{array}$} \\
\hline & & & & & \\
\hline & 25,63 & 7,67 & 24,44 & 5,69 & \\
\hline Weight & 60,43 & 15,37 & 66,17 & 16,08 & 0,099 \\
\hline BMI $\left(\mathrm{k} / \mathrm{m}^{2}\right)$ & 24,25 & 7,68 & 24,80 & 5,88 & 0,436 \\
\hline $\mathrm{HCY} \mu \mathrm{mol} / \mathrm{ml}$ & 10,90 & 3,60 & 12,37 & 4,05 & 0,073 \\
\hline MDA (nMol/ml) & 6,47 & 3,63 & 5,59 & 2,55 & 0,396 \\
\hline NO (microMol/L) & 8,73 & 3,04 & 9,54 & 4,16 & 0,595 \\
\hline $\mathrm{SH}$ (mMol/L) & 6,96 & 6,07 & 10,92 & 7,76 & 0,172 \\
\hline TAFI & 9,89 & 5,06 & 12,14 & 10,01 & 0,563 \\
\hline Fasting Glucose (mg/dl) & 84,39 & 18,27 & 91,79 & 8,99 & 0,005 \\
\hline Fasting insulin $(\mathrm{mlU} / \mathrm{ml})$ & 11,09 & 21,22 & 15,78 & 33,23 & 0,507 \\
\hline Homocysteine $(\mu \mathrm{mol} / \mathrm{L})$ & 1,27 & 1,24 & 3,83 & 9,17 & 0,168 \\
\hline Estradiol $(\mathrm{pg} / \mathrm{ml})$ & 51,65 & 58,40 & 35,13 & 26,82 & 0,052 \\
\hline DHEA-S $(\mu \mathrm{g} / \mathrm{dl})$ & 272,93 & 131,36 & 217,19 & 115,69 & 0,035 \\
\hline 17 -OHP (ng/ml) & 1,10 & 1,05 & 1,85 & 1,04 & 0,002 \\
\hline Total-Testosterone $(\mathrm{ng} / \mathrm{ml})$ & 0,92 & 1,30 & 0,96 & 1,85 & 0,905 \\
\hline Free-Testosterone $(\mathrm{pg} / \mathrm{ml})$ & 1,76 & 0,83 & 3,28 & 2,12 & 0,001 \\
\hline Prolactin (pmol) & 17,09 & 10,76 & 17,01 & 8,00 & 0,969 \\
\hline Total-cholesterol $(\mathrm{mg} / \mathrm{dl})$ & 171,34 & 61,74 & 198,95 & 41,19 & 0,009 \\
\hline Triglycerides (mg/dl) & 88,52 & 50,83 & 124,00 & 69,35 & 0,014 \\
\hline HDL-C (mg/dl) & 59,37 & 16,39 & 57,06 & 15,39 & 0,514 \\
\hline LDL-C (mg/dl) & 98,89 & 31,83 & 117,68 & 31,71 & 0,01 \\
\hline Fibrinogen (mg/dl) & 295,85 & 102,07 & 373,83 & 110,84 & 0,004 \\
\hline
\end{tabular}

levels in patients carrying ABCA1 G2706A polymorphism (Table 4).

IV-Effects of ABCA genotypes on oxidative stress markers, homocystein levels in patients

In our study, the homocystein levels were significantly higher in PCOS patients with ABCA G1051A mutant genotype than those with heterozygote and wild genotypes (Table 3). The ABCA genotypes do not appear to have significant correlation with the plasma Hcy levels, MDA, NO and SH in PCOS patients.

\section{Discussion}

Women with PCOS have multiple risk factors for the development of cardiovascular disease, including hyperandrogenemia, insulin resistance and glucose intolerance, obesity, and central fat deposition [18]. Women with PCOS are also at increased risk for the development of the metabolic syndrome $[19,20]$.

Additionally, different markers of clinical and subclinical atherosclerosis, including serum markers (for example fibrinogen, high sensitive C-reactive protein and homocysteine, oxidative stress markers, PAI-1, TPA), carotid intimae-media thickness, and echocardiographic findings have also been found to be changed [21-25]. In our 
Table 2 Distribution of ABCA haplotypes and genotypes

\begin{tabular}{|c|c|c|c|c|c|c|}
\hline Polymorphism & Genotypes/Haplotypes & $\begin{array}{c}\text { Control } \\
\text { Group } \\
n=93\end{array}$ & $\begin{array}{l}\text { PCOS } \\
\text { Group } \\
n=98\end{array}$ & $O R^{*}$ & $95 \% \mathrm{Cl}^{*}$ & $P^{*}$ \\
\hline \multirow[t]{5}{*}{ G1051A } & GG (Wild type) & $\begin{array}{c}34 \\
36,6 \%\end{array}$ & $\begin{array}{c}30 \\
31,2 \%\end{array}$ & & $\mathrm{R}$ & 0.585 \\
\hline & GA (Heterozygote) & $\begin{array}{c}49 \\
52,7 \%\end{array}$ & $\begin{array}{c}53 \\
53,8 \%\end{array}$ & 0,836 & $0,444-1,574$ & 0,579 \\
\hline & AA (Mutant) & $\begin{array}{c}10 \\
10,8 \%\end{array}$ & $\begin{array}{c}15 \\
15,1 \%\end{array}$ & 0,609 & $0,235-1,577$ & 0,307 \\
\hline & G & $\begin{array}{c}117 \\
62,9 \%\end{array}$ & $\begin{array}{c}114 \\
58,1 \%\end{array}$ & 0.817 & $0.538-1.238$ & 0.396 \\
\hline & A & $\begin{array}{c}69 \\
37,1 \%\end{array}$ & $\begin{array}{c}82 \\
41,9 \%\end{array}$ & & & \\
\hline \multirow[t]{5}{*}{ G2706A } & GG (Wild type) & $\begin{array}{c}55 \\
60,7 \%\end{array}$ & $\begin{array}{c}80 \\
82,6 \%\end{array}$ & & R & 0.004 \\
\hline & GA (Heterozygote) & $\begin{array}{c}30 \\
32,1 \%\end{array}$ & $\begin{array}{c}9 \\
8,7 \%\end{array}$ & 5,029 & $1,922-13,160$ & 0.001 \\
\hline & AA (Mutant) & $\begin{array}{c}8 \\
7,1 \%\end{array}$ & $\begin{array}{c}9 \\
8,7 \%\end{array}$ & 1,118 & $0,339-3,685$ & 0.855 \\
\hline & G & $\begin{array}{c}162 \\
87,0 \%\end{array}$ & $\begin{array}{c}150 \\
76,8 \%\end{array}$ & 2.016 & $1.094-3.714$ & 0.027 \\
\hline & $A$ & $\begin{array}{c}24 \\
13,0 \%\end{array}$ & $\begin{array}{c}46 \\
23,2 \%\end{array}$ & & & \\
\hline
\end{tabular}

Table 3 Biochemical and Hormonal parameters between ABCA G1051A genotypes in patient group

\begin{tabular}{|c|c|c|c|c|c|}
\hline & G1051A Genotype & Mean & SD & $95 \% \mathrm{Cl}$ & $\mathbf{p}$ \\
\hline \multirow[t]{3}{*}{$\mathrm{BMI}\left(\mathrm{k} / \mathrm{m}^{2}\right)$} & GG & 23,64 & 5,11 & $21,62-25,66$ & 0,353 \\
\hline & GA & 25,45 & 6,386 & $23,46-27,44$ & \\
\hline & $\mathrm{AA}$ & 26,3 & 6,277 & $21,81-30,79$ & \\
\hline \multirow[t]{3}{*}{ Fasting Glucose (mg/dl) } & GG & 91,63 & 6,264 & $89,15-94,11$ & 0,291 \\
\hline & GA & 91,79 & 7,537 & $89,44-94,13$ & \\
\hline & $\mathrm{AA}$ & 96,09 & 14,883 & $86,09-106,09$ & \\
\hline \multirow[t]{3}{*}{ Fasting insulin (mlU/ml) } & GG & 10,2394 & 4,98809 & $8,44-12,04$ & 0,001 \\
\hline & GA & 10,7138 & 4,53637 & $9,45-11,97$ & \\
\hline & $\mathrm{AA}$ & 21,5954 & 5,05475 & $8,87-34,32$ & \\
\hline \multirow[t]{3}{*}{ Homocysteine $(\mu \mathrm{mol} / \mathrm{L})$} & GG & 2,3526 & 1,21 & $1,91-2,79$ & 0,003 \\
\hline & GA & 2,3925 & 1,18 & $2,06-2,72$ & \\
\hline & $\mathrm{AA}$ & 4.11 & 3,27 & $2,04-6,19$ & \\
\hline \multirow[t]{3}{*}{ Estradiol (pg/ml) } & GG & 29,57 & 17,069 & $22,36-36,78$ & 0,226 \\
\hline & GA & 40,74 & 33,594 & $29,69-51,78$ & \\
\hline & AA & 29,33 & 12,952 & $19,38-39,29$ & \\
\hline \multirow[t]{3}{*}{ DHEA-S ( $\mu \mathrm{g} / \mathrm{dl})$} & GG & 205,46 & 90,094 & $169,07-241,85$ & 0,645 \\
\hline & GA & 229,45 & 126,715 & $188,92-269,98$ & \\
\hline & $\mathrm{AA}$ & 202,78 & 112,325 & $116,44-289,12$ & \\
\hline \multirow[t]{3}{*}{$17-\mathrm{OHP}(\mathrm{ng} / \mathrm{ml})$} & GG & 1,878 & 0,846 & $1,543-2,212$ & 0,906 \\
\hline & GA & 1,835 & 1,2192 & $1,445-2,225$ & \\
\hline & $\mathrm{AA}$ & 1,709 & 0,8723 & $1,123-2,295$ & \\
\hline \multirow[t]{3}{*}{ Free-Testosterone $(\mathrm{pg} / \mathrm{ml})$} & GG & 3,16 & 2,009 & $2,35-3,97$ & 0,63 \\
\hline & $\mathrm{GA}$ & 3,11 & 2,248 & $2,4-3,82$ & \\
\hline & AA & 3,8 & 1,982 & $2,47-5,13$ & \\
\hline Total-Testosterone $(\mathrm{ng} / \mathrm{ml})$ & GG & 1,278 & 3,0116 & $0,024-2,581$ & 0,582 \\
\hline
\end{tabular}


Table 3 Biochemical and Hormonal parameters between ABCA G1051A genotypes in patient group (Continued)

\begin{tabular}{ccccc}
\hline & GA & 0,748 & 0,8182 & \multicolumn{2}{c}{$0,458-1,039$} \\
\cline { 2 - 5 } & AA & 0,813 & 0,2997 & $0,562-1,063$ \\
\hline Prolactin (pmol) & GG & 17,61 & 9,731 & $13,76-21,46$ \\
\cline { 2 - 5 } & GA & 16,07 & 7,293 & $13,67-18,46$ \\
\cline { 2 - 5 } & AA & 18,8 & 6,125 & $14,42-23,18$ \\
\hline
\end{tabular}

study, no meaningful correlation between homocystein, NO MDA, and SH levels between patient and control groups. Fibrinogen levels were found to be statistically higher in PCOS patients group than the controls. However, homocystein levels were significantly higher in PCOS patients with ABCA G1051A mutant genotype than those with heterozygote and wild genotypes.

Women with PCOS have a higher prevalence and a greater degree of hyperinsulinemia, and insulin resistance than weight-matched control subjects [26-28]. However, in our study, fasting insulin levels were not different from the controls when compared to healthy controls.

Dyslipidemia is a common metabolic abnormality in PCOS, although the reported types and extent of lipid aberrations have been variable $[29,30]$. PCOS women have been demonstrated to have substantially higher TC and LDL levels than control women $<45$-years-old, after adjustment for BMI and hyperinsulinemia [31].

Table 4 Biochemical and Hormonal parameters between G2706A genotypes in PCOS patient group

\begin{tabular}{|c|c|c|c|c|c|}
\hline & G2706A Genotype & Mean & SD & $95 \% \mathrm{Cl}$ & $\mathrm{p}$ \\
\hline \multirow[t]{3}{*}{ BMI $\left(\mathrm{k} / \mathrm{m}^{2}\right)$} & GG & 24,47 & 5,17 & $23,01-25,92$ & 0,071 \\
\hline & GA & 28,42 & 7,01 & $21,06-35,77$ & \\
\hline & AA & 20,63 & 1,25 & $18,64-22,61$ & \\
\hline \multirow[t]{3}{*}{ Fasting Serum Glucose (mg/dl) } & GG & 92,82 & 10,28 & $89,93-95,71$ & 0,691 \\
\hline & GA & 89,83 & 6,94 & $82,55-97,12$ & \\
\hline & $\mathrm{AA}$ & 90,00 & 4,32 & $83,13-96,87$ & \\
\hline \multirow[t]{3}{*}{ Fasting insulin (mlU/ml) } & GG & 12,5701 & 10,69 & $10,04-15,10$ & 0.560 \\
\hline & GA & 9,6271 & 4,12 & $7,25-12,00$ & \\
\hline & AA & 11,5217 & 4,24 & $8,82-14,22$ & \\
\hline \multirow[t]{3}{*}{ Homocysteine $(\mu \mathrm{mol} / \mathrm{L})$} & GG & 2,7138 & 1,84 & $2,27-3,15$ & 0.491 \\
\hline & GA & 2,1653 & 0,97 & $1,60-2,73$ & \\
\hline & $\mathrm{AA}$ & 2,3987 & 1,21 & $1,63-3,17$ & \\
\hline \multirow[t]{3}{*}{ Estradiol $(\mathrm{pg} / \mathrm{ml})$} & GG & 34,72 & 28,55 & $26,43-43,01$ & 0,499 \\
\hline & GA & 45,75 & 30,71 & $3,11-94,61$ & \\
\hline & $\mathrm{AA}$ & 50,50 & 47,90 & $25,72-126,72$ & \\
\hline \multirow[t]{3}{*}{ DHEA-S $(\mu \mathrm{g} / \mathrm{dl})$} & GG & 216,10 & 101,88 & $186,52-245,69$ & 0,079 \\
\hline & GA & 302,67 & 156,34 & $138,60-466,74$ & \\
\hline & AA & 148,75 & 100,73 & $11,54-309,04$ & \\
\hline \multirow[t]{3}{*}{$17-\mathrm{OHP}(\mathrm{ng} / \mathrm{ml})$} & GG & 1,992 & 1,14 & $1,664-2,320$ & 0,823 \\
\hline & $\mathrm{GA}$ & 1,767 & 1,13 & $0,584-2,950$ & \\
\hline & AA & 1,725 & 0,60 & $0,767-2,683$ & \\
\hline \multirow[t]{3}{*}{ Prolactin (pmol) } & GG & 17,20 & 8,87 & $14,62-19,77$ & 0,758 \\
\hline & GA & 15,50 & 4,28 & $11,01-19,99$ & \\
\hline & AA & 14,50 & 3,51 & $8,91-20,09$ & \\
\hline \multirow[t]{3}{*}{ Free-Testosterone (pg/ml) } & GG & 3,49 & 2,48 & $2,77-4,20$ & 0,839 \\
\hline & GA & 3,92 & 1,48 & $2,36-5,47$ & \\
\hline & AA & 3,03 & 1,19 & $1,13-4,92$ & \\
\hline \multirow[t]{3}{*}{ Total-Testosterone $(\mathrm{ng} / \mathrm{ml})$} & GG & 1,041 & 2,32 & $0,288-1,794$ & 0,671 \\
\hline & GA & 1,900 & 1,96 & $1,224-5,024$ & \\
\hline & $\mathrm{AA}$ &, 525 & 0,30 & $0,050-1,000$ & \\
\hline
\end{tabular}


IR represents another key factor implicated in the dyslipidemia of PCOS. Glueck et al. reported that $46 \%$ of women with PCOS suffered from the metabolic syndrome [32]. Within this subgroup of women, lipid abnormalities were found to be extremely common. 95\% of these women demonstrated decreased levels of high-densitylipoprotein (HDL), whereas 56\% had hypertriglyceridemia. In this study, no difference was determined in PCOS patient group in terms of HDL cholesterol when compared to the controls, while TG values were determined to be statistically meaningfully high in patient group. In this study, LDL cholesterol and total cholesterol levels were found to be statistically meaningfully high in PCOS patient group when compared to the controls.

IR and compensatory hyperinsulinemia are considered to be main responsible for the lipidemic aberrations of obesity and PCOS. Besides, genetic factors may also contribute to the formation of dyslipidemia in PCOS disease [33]. Members of the ATP-binding cassette (ABC) transporter family, such as ABCA1, have been shown to control cellular lipid metabolism $[34,35]$. Changes happened in ATP binding cassette transporter 1 ( $\mathrm{ABC} 1$ ) gene encoding a protein regulating entry and exit from cell membrane may contribute to dyslipidemia in patients with PCOS.

Jerome I. Rotter et al. found a relation between ABCA1 G1051A polymorphism and HDL-cholesterol elevation. This relation conflicts with previous studies. Again, these researchers determined a correlation between ABCA1 G1051A gene polymorphism and moderate LDL-cholesterol lowness [36,37]. In our study, the genotype ABCA G1051A distribution didn't differ between control and PCOS groups. However, the distribution of ABCA G2706A genotype differed between the control group and the PCOS patients. Frikke-Schmidt et al. determined higher G2706A gene polymorphism allele in patient group with low HDL cholesterol [38]. In our study, the frequency of the polymorphic A allele of ABCA G2706A gene was higher in PCOS patients than control group.

There was no statistically significant difference in PCOS patients between ABCA G1051A genotypes (AA, GA and GG) and BMI, fasting insulin, fasting glucose, triglyceride levels, HDL levels, LDL levels, fasting blood glucose levels, f-testosterone, fibrinogen and 17-OHP levels. However, in PCOS patients, fasting insulin levels and homocystein were found to be significantly higher in ABCA G1051A mutant genotype than heterozygote and wild genotypes.

In conclusion, we found AA genotype and A allele of ABCA G2706A in PCOS patients. The fasting insulin and homocystein levels were significantly higher in PCOS patients with ABCA G1051A mutant genotype than those with heterozygote and wild genotypes. However, it is determined that ABCA1 G2706A and ABCA G1051A polymorphisms have no effect on lipid oxidative stress parameters in patients. Future studies should explain the specific roles of other genes (e.g CETP, LDL receptor and hepatic lipase) in the pathophysiology of dyslipidemias in PCOS.

\section{Author details}

${ }^{1}$ Department of Endocrinology, Ege University School of Medicine, Izmir, Turkey. ${ }^{2}$ Department of Biochemistry, Ege University School of Medicine, Izmir, Turkey. ${ }^{3}$ Department of Medical Biology, Ege University School of Medicine, Izmir, Turkey. ${ }^{4}$ Ege University Hospital, Ege University School of Medicine, Department of Pharmacology, Izmir, Turkey. ${ }^{5}$ Division of Internal Medicine, Sifa University, Health Application and Research Center, Izmir, Turkey. ${ }^{6}$ Department of Endocrinology, Sifa University, Health Application and Research Center, Izmir, Turkey.

\section{Authors' contributions}

In this study, MK, VC, AT carried out the molecular genetic studies, SC, FS, AGO, CY conceived of the study, and participated in its design and coordination. AZ, MY, participated in the sequence alignment and drafted the manuscript. MK, ME participated in the design of the study and performed the statistical analysis and participated in the sequence alignment. $\mathrm{MO}$, carried out the immunoassays. All authors read and approved the final manuscript.

\section{Competing interests}

The authors declare that they have no competing interests.

Received: 18 August 2011 Accepted: 28 October 2011

Published: 28 October 2011

\section{References}

1. Chang RJ: A practical approach to the diagnosis of polycystic ovary syndrome. Am J Obstet Gynecol 2004, 191:713-7.

2. King J: Polycystic ovary syndrome. J Midwifery Womens Health 2006, 51:415-22.

3. Otto-Buczkowska E, Jarosz-Chobot P, Deja G: [Early metabolic abnormalities-insulin resistance, hyperinsulinemia, impaired glucose tolerance and diabetes, in adolescent girls with polycystic ovarian syndrome]. Przegl Lek 2006, 63:234-8.

4. Barutcuoglu B, Bozdemir AE, Dereli D, Parildar Z, Mutaf Ml, Ozmen D, Bayindir O: Increased serum neopterin levels in women with polycystic ovary syndrome. Ann Clin Lab Sci 2006, 36:267-72.

5. Refsum H, Ueland PM, Nygard O, Vollset SE: Homocysteine and cardiovascular disease. Annu Rev Med 1998, 49:31-62.

6. Gadducci A, Gargini A, Palla E, Fanucchi A, Genazzani AR: Polycystic ovary syndrome and gynecological cancers: is there a link? Gynecol Endocrinol 2005, 20:200-8.

7. Balen A: Polycystic ovary syndrome and cancer. Hum Reprod Update 2001, 7:522-5.

8. Legro RS, Kunselman AR, Dunaif A: Prevalence and predictors of dyslipidemia in women with polycystic ovary syndrome. Am J Med 2001, 111:607-613.

9. Berneis K, Rizzo M, Lazzarini V, Fruzzetti F, Carmina E: Atherogenic lipoprotein phenotype and low density lipoproteins size and subclasses in women with polycystic ovary syndrome. J Clin Endocrinol Metab 2007, 92:186-189.

10. Glueck CJ, Papanna R, Wang P, Goldenberg N, Sieve-Smith L: Incidence and treatment of metabolic syndrome in newly referred women with confirmed polycystic ovarian syndrome. Metabolism 2003, 52:908-915.

11. Conway GS, Agrawal R, Betteridge DJ, Jacobs HS: Risk factors for coronary artery disease in lean and obese women with the polycystic ovary syndrome. Clin Endocrinol (Oxf) 1992, 37:119-125.

12. Oram JF: Tangier disease and ABCA1. Biochim Biophys Acta 2000, 1529:321-30.

13. Luciani MF, Chimini G: The ATP binding cassette transporter $A B C 1$, is required for the engulfment of corpses generated by apoptotic cell death. EMBO J 1996, 15:226-35.

14. The Rotterdam ESHRE/ASRM-Sponsored PCOS consensus workshop group: Revised 2003 consensus on diagnostic criteria and long-term health 
risks related to polycystic ovary syndrome (PCOS). Hum Reprod 2004, 19:41-7.

15. Yagi K: Lipid peroxides in hepatic, gastrointestinal and pancreatic diseases. In Free radicals in Diagnostic Medicine. Edited by: Armstrong D. New York, NY, Plenum Press; 1994:165-169.

16. Miranda KM, Espey MG, Wink DA: A rapid, simple spectrophometric method for simultaneous detection of nitrate and nitrite. Nitric Oxide 2001, 5:62-71.

17. Sedlak J, Lindsay RH: Estimation of total, protein-bound and nonprotein sulfhydryl groups in tissue with Ellman's reagent. Anal Biochem 1968, 25:192-205.

18. Tsilchorozidou T, Overton C, Conway GS: The pathophysiology of polycystic ovary syndrome. Clin Endocrinol (Oxf) 2004, 60:1-17.

19. Apridonidze T, Essah PA, luorno MJ, Nestler JE: Prevalence and characteristics of the metabolic syndrome in women with polycystic ovary syndrome. J Clin Endocrinol Metab 2005, 90:1929-1935.

20. Wild R: Polycystic ovary syndrome: A risk for coronary artery disease? Am J Obstet Gynecol 2002, 186:35-43.

21. Tarkun I, Arslan BC, Cantürk Z, Türemen E, Sahin T, Duman C: Endothelial dysfunction in young women with polycystic ovary syndrome: relationship with insulin resistance and low-grade chronic inflammation. J Clin Endocrinol Metab 2004, 89:5592-6.

22. Tarkun I, Cetinarslan B, Türemen E, Sahin T, Cantürk Z, Komsuoglu B: Effect of rosiglitazone on insulin resistance, C-reactive protein and endothelial function in non-obese young women with polycystic ovary syndrome. Eur J Endocrinol 2005, 153:115-21.

23. Karadeniz M, Erdogan M, Berdeli A, Tamsel S, Saygili F, Yilmaz C: The progesterone receptor PROGINS polymorphism is not related to oxidative stress factors in women with polycystic ovary syndrome. Cardiovasc Diabetol 2007, 5:6-29.

24. Karadeniz M, Erdogan M, Berdeli A, Saygili F, Yilmaz C: 4 G/5 G polymorphism of PAI-1 gene and Alu-repeat I/D polymorphism of TPA gene in Turkish patients with polycystic ovary syndrome. J Assist Reprod Genet 2007, 24:412-8.

25. Karadeniz M, Erdoğan M, Tamsel S, Zengi A, Alper GE, Cağlayan O, Saygili F, Yilmaz C: Oxidative stress markers in young patients with polycystic ovary syndrome, the relationship between insulin resistances. Exp Clin Endocrinol Diabetes 2008, 116:231-5.

26. Dunaif A, Graf M, Mandeli J, Laumas V, Dobrjansky A: Characterization of groups of hyperandrogenic women with acanthosis nigricans, impaired glucose tolerance, and/or hyperinsulinemia. J Clin Endocrinol Metab 1987, 65:499-507.

27. Conway GS, Jacobs HS, Holly JM, Wass JA: Effects of luteinizing hormone, insulin, insulin-like growth factor-I and insulin-like growth factor small binding protein 1 in the polycystic ovary syndrome. Clin Endocrinol (Oxf) 1990, 33:593-603.

28. Dunaif A, Segal KR, Futterweit W, Dobrjansky A: Profound peripheral insulin resistance, independent of obesity, in polycystic ovary syndrome. Diabetes 1989, 38:1165-1174.

29. Wild RA, Painter PC, Coulson PB, Carruth KB, Ranney GB: Lipoprotein lipid concentrations and cardiovascular risk in women with polycystic ovary syndrome. J Clin Endocrinol Metab 1985, 61:946-951.

30. Rajkhowa M, Neary RH, Kumpatla P, Game FL, Jones PW, Obhrai MS, Clayton RN: Altered composition of high density lipoproteins in women with the polycystic ovary syndrome. J Clin Endocrinol Metab 1997, 82:3389-3394.

31. Talbott E, Clerici A, Berga SL, Kuller L, Guzick D, Detre K, Daniels T, Engberg RA: Adverse lipid and coronary heart disease risk profiles in young women with polycystic ovary syndrome: results of a case-control study. J Clin Epidemiol 1998, 51:415-422.

32. Glueck CJ, Papanna R, Wang P, Goldenberg N, Sieve-Smith L: Incidence and treatment of metabolic syndrome in newly referred women with confirmed polycystic ovarian syndrome. Metabolism 2003, 52:908-915.

33. Cetinkalp S, Karadeniz M, Erdogan M, Zengi A, Cetintas V, Tetik A, Eroglu Z, Kosova B, Ozgen AG, Saygili F, Yilmaz C: Apolipoprotein E gene polymorphism and polycystic ovary syndrome patients in Western Anatolia, Turkey. J Assist Reprod Genet 2009, 26:1-6.

34. Oram JF, Lawn RM: ABCA1: the gatekeeper for eliminating excess tissue cholesterol. J Lipid Res 2001, 42:1173-1179.
35. Wang N, Silver DL, Thiele C, Tall AR: ATP-binding cassette transporter A1 (ABCA1) functions as a cholesterol efflux regulatory protein. $J$ Biol Chem 2001, 276:23742-23747.

36. Benton JL, Ding J, Tsai MY, Shea S, Rotter Jl, Burke GL, Post W: Associations between two common polymorphisms in the ABCA1 gene and subclinical atherosclerosis: Multi-Ethnic Study of Atherosclerosis (MESA). Atherosclerosis 2007, 193:352-60.

37. Cenarro A, Artieda M, Castillo S, Mozas P, Reyes G, Tejedor D, Alonso R, Mata P, Pocoví M, Civeira F, Spanish FH group: A common variant in the $A B C A 1$ gene is associated with a lower risk for premature coronary heart disease in familial hypercholesterolaemia. J Med Genet 2003, 40:163-168.

38. Frikke-Schmidt, Nordestgaard BG, Jensen GB, Tybjaerg-Hansen A: Genetic variation in $A B C$ transporter $A 1$ contributes to $H D L$ cholesterol in the general population. J Clin Invest 2004, 114:1343-1353.

doi:10.1186/1476-511X-10-193

Cite this article as: Karadeniz et al:: Effect Of G2706A and G1051A

polymorphisms of the ABCA1 gene on the lipid, oxidative stress and homocystein levels in Turkish patients with polycystıc ovary syndrome. Lipids in Health and Disease 2011 10:193.

\section{Submit your next manuscript to BioMed Central and take full advantage of:}

- Convenient online submission

- Thorough peer review

- No space constraints or color figure charges

- Immediate publication on acceptance

- Inclusion in PubMed, CAS, Scopus and Google Scholar

- Research which is freely available for redistribution

Submit your manuscript at www.biomedcentral.com/submit
Ciomed Central 